\title{
An Anthropological View of Nutrition and Art in Wider Area of Selška Valley, Slovenia
}

\author{
Maruška Vidovič, Marjetka Jelenc \\ National Institute of Public Health, Ljubljana, Slovenia
}

\begin{abstract}
A B S T R A C T
The paper presents nutrition as a fundamental biological function in connection with art from wider Šskofjeloško-Selška area on the examples of medieval wall paintings-frescoes, painted beehive panels and examples of folk art such as small breads, Dražgoše breads and some other folk arts related to nutrition. The study on nutrition and art was included in the multi-year project Research of the Population Structures of Slovenia, with which we determine the types of populations, the direction of their development, their ecological, genetic and other effects, as well as their interactions.
\end{abstract}

Key words: nutrition, art, medieval frescoes, painted beehive extensions, folk art

\section{Introduction}

Nutrition is one of the most basic and unavoidable human needs, which has a fundamental biological function. It must cover a person's daily energy needs, as well as the need for nutrients, which also affects the health status of people. As part of our most extensive anthropological and public health project Research of the Population Structures of Slovenia, we were also researching nutrition on a research model of populations from the villages of the closed hilly Selška valley in northwestern Slovenia, where our research was conducted ${ }^{1-3}$. Research on population structures represents the full spectrum of biological, sociological and demographic factors influencing the genetic structure of a population. They are a set of dynamic formation of population characteristics at the time of evolution and in space - in an ecological niche. Research on population structures can be performed at different levels and is mainly based on analyzes of demographic data, serological data and biological properties of the human body (analyzes of morphological, anthropometric, odontometric, dermatoglyphic and physiological data). Research on population structures can also be used to trace (micro) evolution processes that can occur in one or some generations, especially in reproductively closed populations affected by genetic drift. This area is anthropologically very interesting due to its special geographical location, historical events (colonization), local socio-cultural features and special ecological conditions. Extensive holistic anthropological research on population structures has enabled us to reach many important conclusions about the population living in the valley between the wider region of Selška valley. We learned a lot about the nutrients of the historical population from duty-based land registers. There are many specialties and traditional elements in the diet of the described population. Through an understanding of eating practices, however, we can also analyze many other areas of human existence $^{4-10}$.

When we studied nutrition in the villages of the Selška valley as part of the project Research of the Population Structures of Slovenia with the help of international questionnaires, the International Commission on the Anthropology of Food and Nutrition (ICAF) tests and interviews with the respondents, we visited fifty nine households. The results of the research have been presented at conferences. During the field research work we were in direct contact with the population, we got to know their way of life, so we were very interested in observing, getting to know and recording the cultural and artistic tradition. At the end we interconnected all these elements. Our guideline was the holistic approach ${ }^{4-10}$.

The aim of this paper is to use a selection of art works in wider Škofjeloško-Selška area that refer to food in order to determine continuity of nutritional habits throughout history and to discuss what we can learn from the art of the past, how to interpret symbols and decorative elements, and the details of the cooking and presentation of meals.

\section{Traditional Food in Gorenjska Region}

Although Slovenia is very small, the diet of the eastern part of Slovenia is very different from the western part. Different researchers, archaeologists, historians and eth- 
nologists conducted studies in Gorenjska region in the last 50 years. For example, Pleterski investigated kitchen culture in the early Middle Ages and Makarovič studied nutrition in the $19^{\text {th }}$ century, including food and dishes by individual regions, daily meals, a value scale of dishes, eating habits, festive and symbolic dishes, and kitchen equipment in the $19^{\text {th }}$ century ${ }^{11-12}$. One of the most interesting sources is undoubtedly Makarovič's contribution "Kitchen equipment, kitchens, cookbooks and food in the $17^{\text {th }}$ century in Slovenia" which was published in 1986. As a source for the $15^{\text {th }}$ century, he used the Figuresque notes of the secretary of the Patriarch of Aquileia, Paolo Santonino, from three business trips to Carinthia, Gorizia, Carniola and Styria from 1485 to $1487^{13-14}$.

From the literature cited above, we came to the conclusion that people in Upper Gorenjska from 15th to 19th century mostly ate simple seasonal food, which they produced with their own hands in the field or garden, while meat was on the table only for major holidays. The main ingredients of peasant menus in Gorenjska were floury dishes (especially buckwheat), dairy dishes, legumes, vegetables (especially cabbage), fruits (especially apples and pears), sauer- kraut and sour beets, and rye-buckwheat bread. They had fresh meat at the time of slaughter, either when they slaughtered poultry or pig, or when caught fish or smaller wild animals. The pig meat was preserved with salt and dried.

\section{Food and Nutrition in Works of Art in Goren- jska Region}

In the frame of our study we found different elements of connection between nutrition and art in the Selška valley and its surroundings. Nutrition elements were found on medieval wall paintings-frescoes, on painted beehive panels, in the artistically made honey Loka breads and Dražgoše breads, as well as in the artistically shaped butter models and on some other useful objects from everyday life. Medieval mural paintings on the walls of churches were a sort of didactic aids for the illiterate, illustrating key religious ideas, images and stories that the parishioners were expected to know. Paintings of Christian teaching depicted behavioural and moralistic images in accordance with the Christian doctrine using scenes from contemporary everyday life.

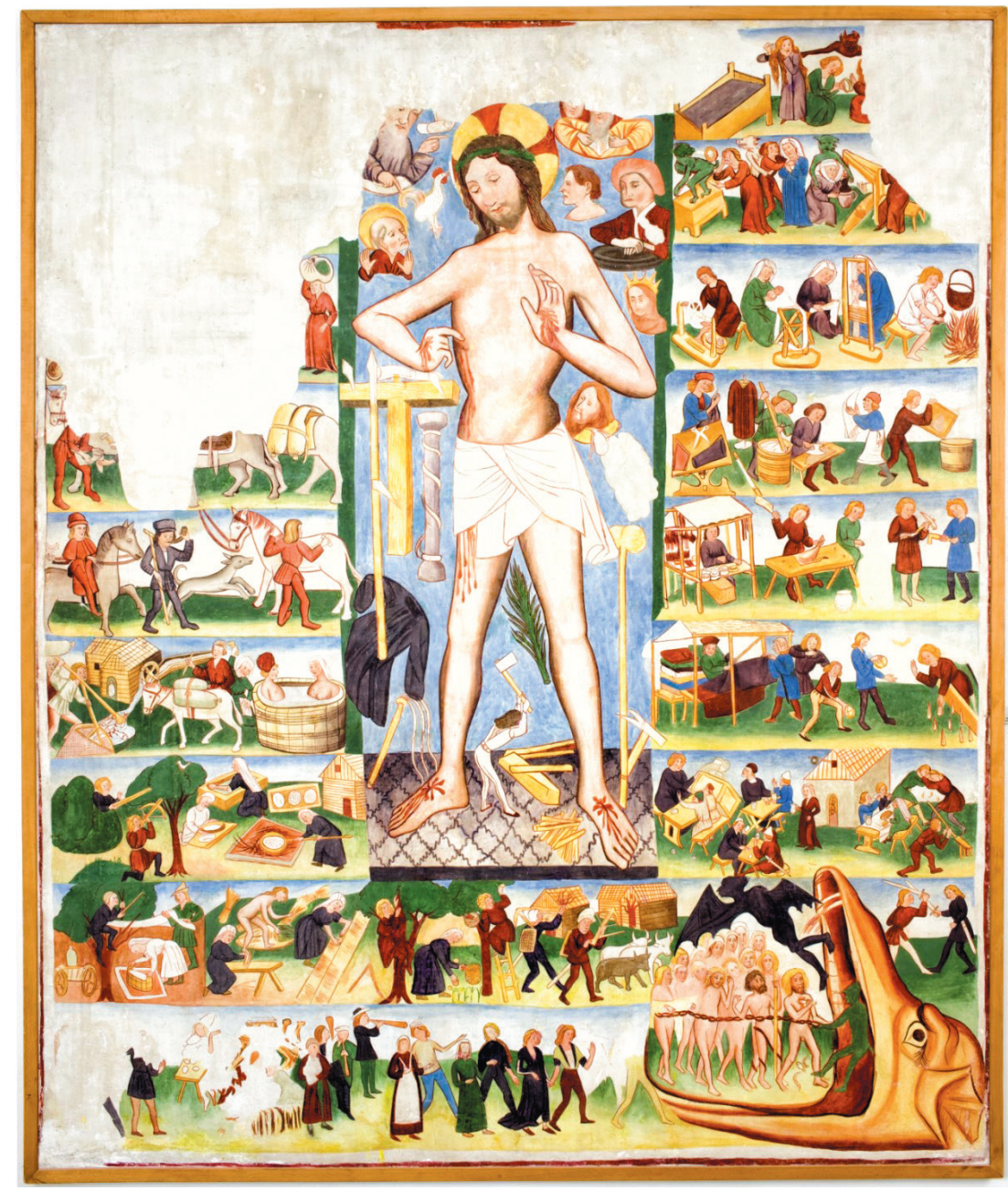

Fig 1. Copy of the fresco of the St Sunday from Crngrob; Škofja Loka Museum. 


\section{Medieval wall-paintings}

\section{St Sunday}

Very impressive, very rich in content, very interesting and very special is the fresco, named St Sunday on the front of the pilgrimage church of the Annunciation of St Mary in Crngrob above Škofja Loka (Figure 1). The fresco was painted in the first half of the $15^{\text {th }}$ century and is attributed to the painter Janez Ljubljanski. The confession of this medieval fresco is that Sunday is the holiest day of the week and that certain tasks may not be performed on this day. The iconographic motive with the central image of the suffering Christ addresses a simple believer who could not read. Thus, Christian art replaced words for illiterate people. In nine parallel horizontal bands, miniature scenes from everyday life are painted, especially activities that are forbidden on Sundays. Although the fresco has a distinctly religious significance, local scenes of everyday works are painted. This imposing fresco opus is a remarkable monument. From the depicted scenes, much can be learned about the artisan life of that time, about the social conditions, the organization of society and the feeling of that time.

Some of the depicted activities are related to food or food preparation. The baking of bread is illustrated in detail: the wife sows flour, the other kneads the dough, the loaves are placed in the oven with a racket, and the loaves are already baked on the table outside. Such an extensive depiction of baking bread proves the importance of bread, which was the basic food of the broadest social strata. In the Middle Ages, the craft of baking developed in towns and squares. A scene of two men picking fruit on a tree, probably apples, and the wife picking them under the tree is also recognizable. The left side of the fresco depicts hunting, which is also related to food. Next to this scene we can see a young man fishing with a net and hunters shooting birds on a tree. It is also presented how people chase a horse that loads an abundant load of grain into the mill. Cattle are partially seen on this scene as well. We can also see a man taking two goats and the work of a butcher dissecting a slaughtered animal (a pig), while a woman in the same scene seems to sell dried meat, sausages and cheese. Some adjacent scenes are not seen in detail. Peasant works are less visible. Another woman carries a field crop on her head. On the right side of the fresco, we can see scenes representing inn drinking. In terms of food and chores, both women and men are painted.

Making a summary of the visual analysis and considering nutrients, we can say that in those times people used venison, meat of game birds, fish, cattle meat and milk, pork, goat meat and milk, legumes, flour for baking bread and other floury dishes, fruit and drinks. It is difficult to observe something with certainty about vegetables. These are all elements that belong to the traditional diet, which also corresponds to written sources on nutrition in history ${ }^{11}$. From these scenes, we can conclude that meat was ranked higher than vegetables in the diet at the time.
The scenes on the fresco present a kind of sermon on forbidden tasks to farmers and citizens. Forty seven scenes are presented in the fresco. Some scenes are blurry, impossible to decipher; the worst preserved figures are at the bottom of the fresco. The moral significance and warning of paintings in the context of Christian doctrine is that by disobedience, by ignoring church rules, we increase the suffering of Christ and earn punishment for ourselves. In the lower right corner there is a wide throat of the hellish dragon which will swallow those who do not follow these church rules.

The depictions show the medieval way of life on our soil ${ }^{15}$ and are anthropologically extremely interesting. In our paper, we mainly focused on diet-related scenes. But there are many other very interesting scenes, which include growing flax, spinning threads, weaving and dyeing canvas, and other handicrafts. The elements of clothing among the townspeople and farmers are also nicely depicted. This wonderful wall painting is a great specialty on a global scale. The fresco has so far been researched by scientists from an iconographic, artistic and ethnographic point of view. Regarding the researchers of the fresco with important findings and explanations we must mention Baš, who vividly described the costumes from the fresco and Stele, Koman, Cevc, as well as Sedej ${ }^{16-20}$.

\section{The content of the legend of St Urh}

On Križna gora above Škofja Loka, inside the church of St Cross there are works of the painter Jernej from Loka, from 1502, which represent an important cultural heritage and are classified as the pinnacle of late Gothic realism ${ }^{21}$. The semantic content of these frescoes is also related to the nutrition and the commandments of fasting. The wall paintings of an unknown Bavarian painter in the presbytery depict legends from the life of St Urh and St Corbinian. The painted scenes (Figures 2 and 3) narrate that St Urh wanted to entertain St Corbinian, ignoring the fact that time had already turned into a new day dedicated to fasting and offered him a chicken thigh. St Corbinian's messenger accused him and decided to explain this fact to the church dignitaries. As a proof, he pulled the thigh out of the bag, which in the meantime miraculously turned into a fish ${ }^{21}$.

The content of this legend, which is painted on the fresco in the church on Križna gora, refers to fasting, which is an obligatory religious ritual and which has great significance in the Christian church. Fasting also has historical significance, as it is already mentioned in the Bible. Fasting is fulfilled by refraining from meat dishes in general and in restricting food and drink. The spiritual significance of fasting is to encourage deep spirituality, prayer, and good works. All this was also physically expressed by people through fasting, because through giving up a person becomes stronger. Fasting, which was originally considered a religious practice, became important also from a health perspective as a "cleansing of body and soul". The ancient Egyptians in the $15^{\text {th }}$ century BC considered too much food as harmful. In the $6^{\text {th }}$ century BC the ancient Greeks were convinced that fasting increases the ability to think. In the $4^{\text {th }}$ century BC Tibetans used fasting as treatment. Hippo- 


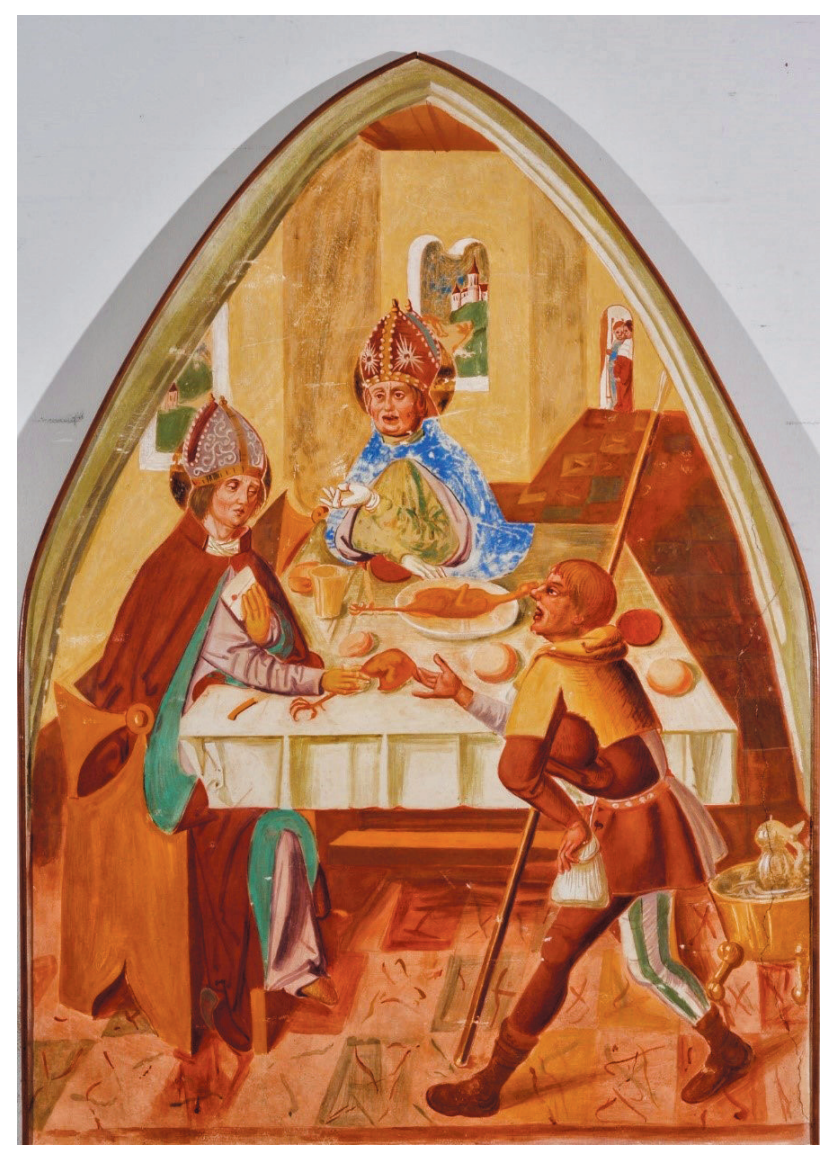

Fig. 2. The copy of the fresco of the legend of St Urh from the Križna gora; National Gallery of Slovenia (The thigh scene).

crates, the most famous ancient Greek physician, found that satiety was the source of the disease. According to the Catholic calendar fasting starts on Ash Wednesday and lasts until Easter. People who practiced religious fasting ate more fish, especially the upper classes, and the lower classes ate mainly floury dishes, bread, vegetables and legumes during fasting.

\section{Painted beehive panels}

Beekeeping is a traditional agricultural activity in Slovenia, with a long history particularly in today's Gorenjska region. Painted beehive panels, small painted planks that enclose the beehive are an autochthonous cultural element, ethnographic originality, the greatest Slovenian specialty. It dominated among members of the peasant social strata and had cultural and historical content, mental meaning and artistic language. The sources of motifs were very diverse, very rich in motives and colors. It was also a visual culture due to the poor literacy of the population. Painted beehive extensions also served to mark the hives. In connection with the cultivation of bees in hives, in the Middle Ages - in the $17^{\text {th }}$ century began to make wooden hives. The oldest beehive extension dates from 1758. Painted beehive panels represent folk art, typical of Slovenia, created in Gorenjska region. The stories painted on beehive panels are

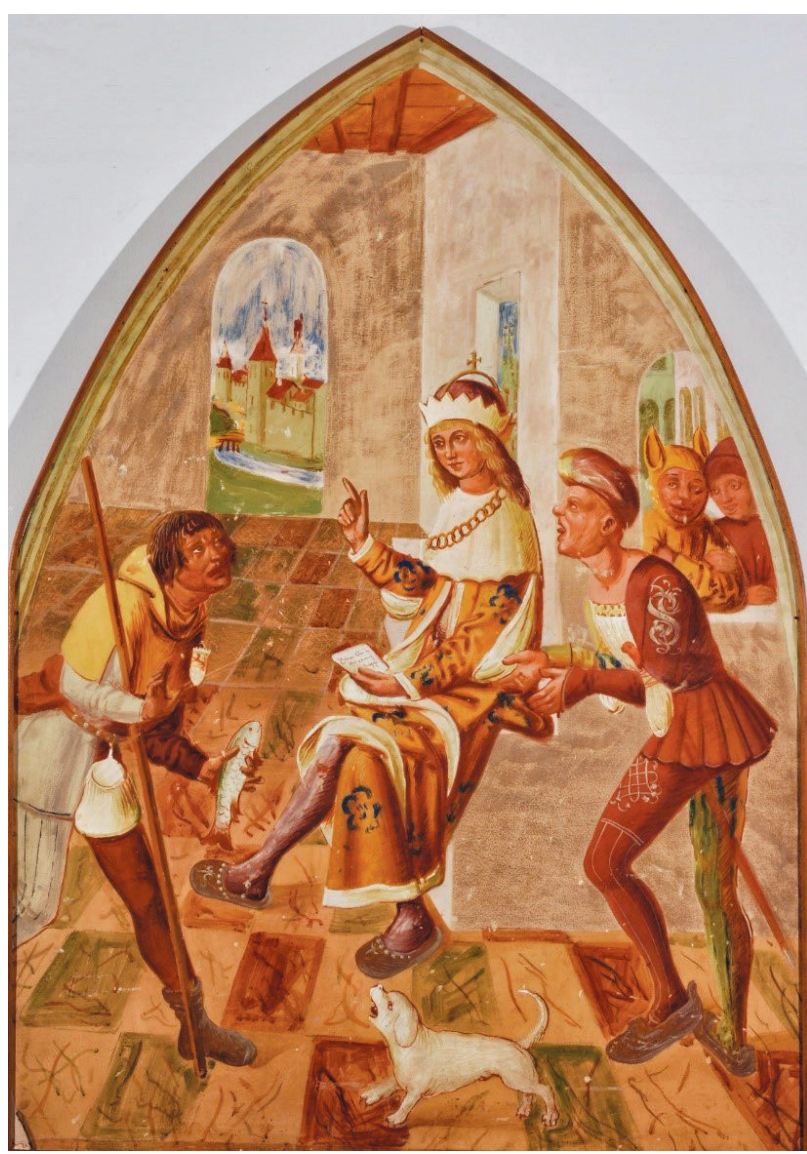

Fig.3. The copy of the fresco of the legend of St Urh from the Križna gora; National Gallery of Slovenia (The fish scene).

associated also with nutrition, as honey and bee products are known from history, first as a substitute for sugar and later as valuable nutrients used also in folk medicine. The honey bee and honey have been known since ancient civilizations. Due to its biological values, honey occupies an important place in the human diet today. After 1800, honey extraction became an economic activity. Painted beehive endings appeared in the mid-18 ${ }^{\text {th }}$ century with figural motifs $^{22.23}$. Their heyday was between 1820 and 1880. In the Slovenian Alpine area, they became most widespread in the $19^{\text {th }}$ century ${ }^{24}$. The painted beehive endings depict priceless stories from the past to the end of World War II, which have important cultural and historical significance.

Figures 4-6 show three copies of the painted beehive extensions. On the first one the wedding in Cana of Galilee with the year 1882 is painted. The motif is religious, the story is from the Bible. Christ, his mother and disciples were invited to the wedding. When the wine ran out, Christ miraculously turned water into wine. Plates, glasses, a bottle and a goblet are painted on the table, and there are larger bottles for storing wine on the floor. On the second painted beehive extension, dated 1848 a husband and wife are painted. The motif of a husband and wife at the table is a secular motif from everyday life; it shows a husband and wife toasting each other. A loaf of bread, a 


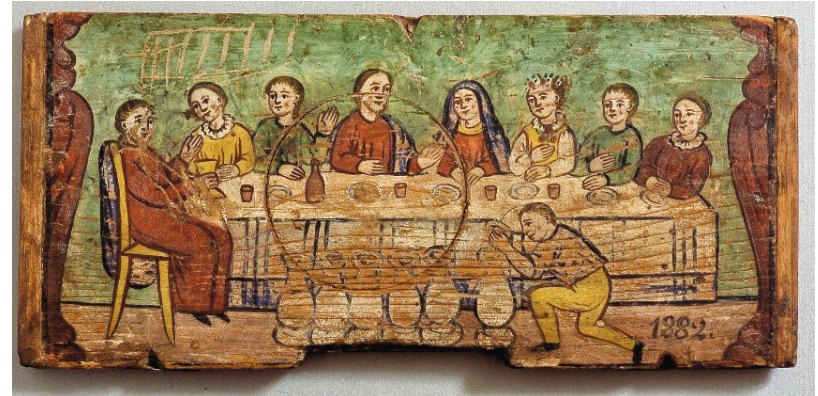

Fig 4. Example of a beehive panel depicting the wedding in Cana of Galilee; Radovljica Beekeeping Museum.

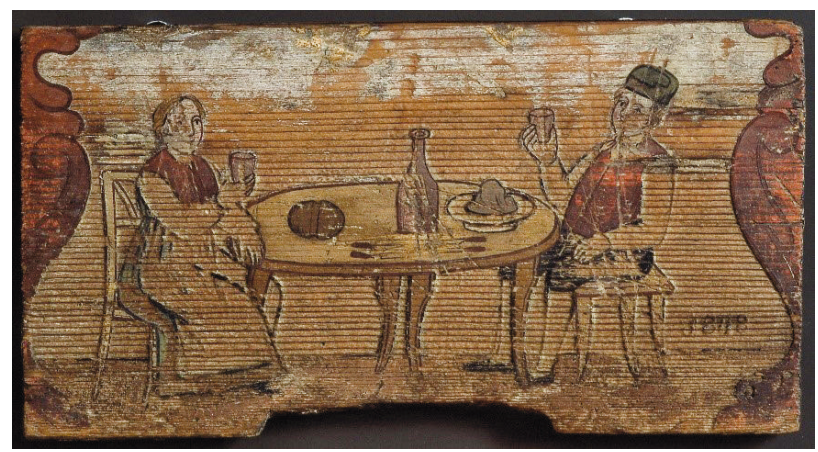

Fig 5. Example of a beehive panel depicting husband and wife eating; Radovljica Beekeeping Museum

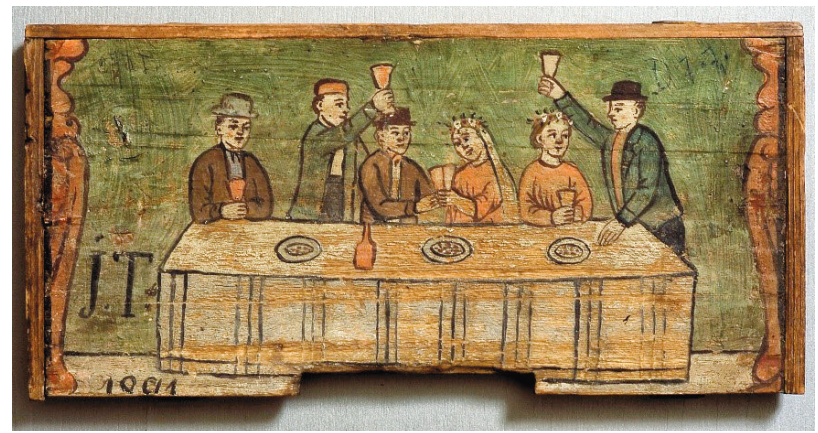

Fig 6. Example of a beehive panel depicting a wedding celebration; Radovljica Beekeeping Museum

bottle, knives and a plate are painted on the table. The symbolic message of the motif is that husband and wife share things in life; they cut the loaf, other foodstuffs and give it to each other. On the third painted behive extension, dated 1891 the wedding is painted. The motif is secular from everyday and festive life. It depicts a peasant wedding, a marriage that had a great significance in the life of every community and is therefore also depicted on the painted beehive extensions. There were always a lot of people at the wedding (relatives, friends, witnesses). Only the married couple and witnesses (closest wedding guests) are depicted on the panel. At weddings, people drank and ate a lot, which is suggested here by the botlle and the plates full of food on the table. Above all, the importance of toasting is indicated ${ }^{25,26}$.

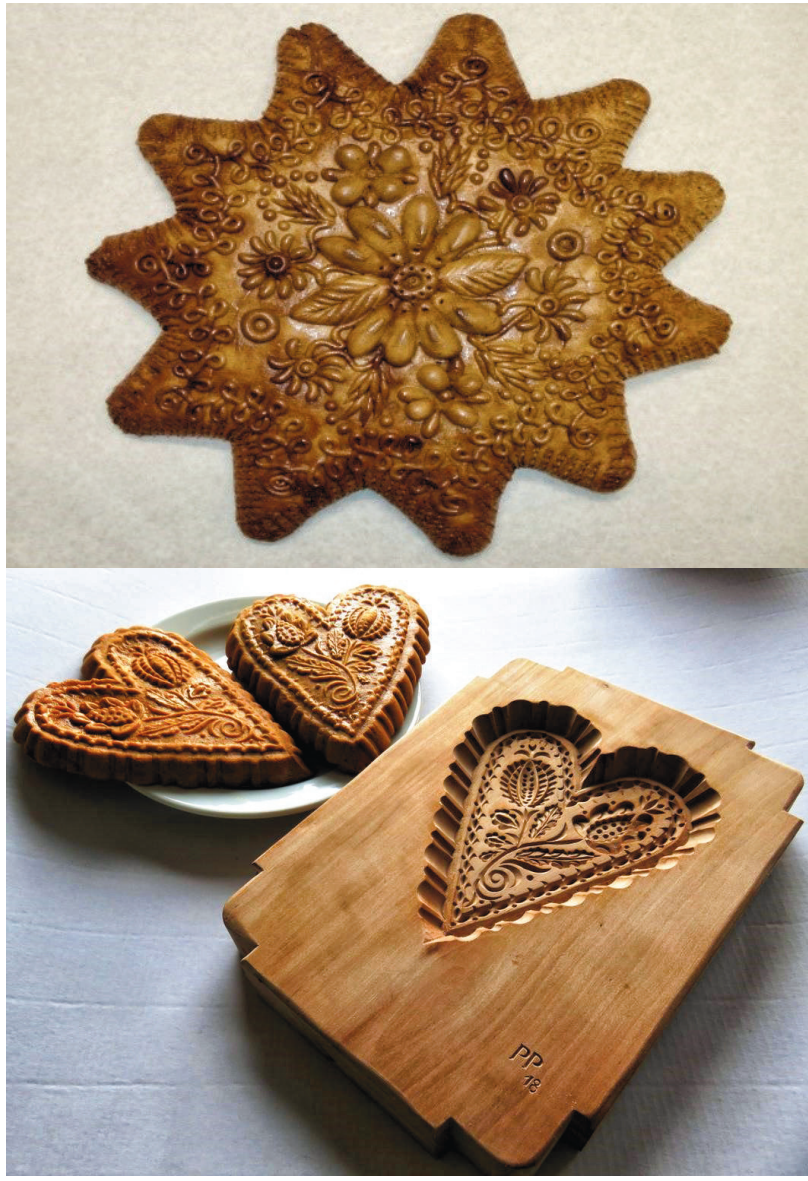

Fig. 7. Small Loka breads.

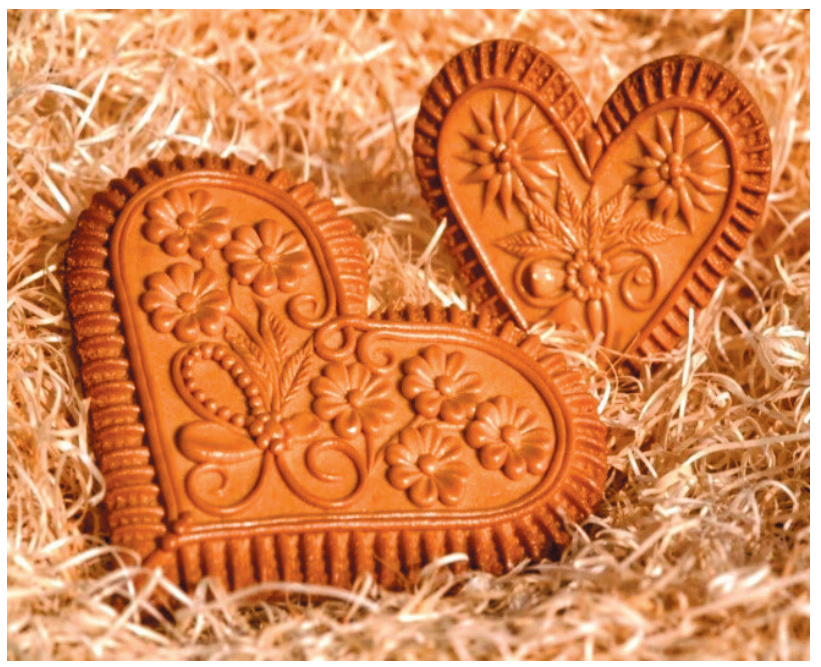

Fig. 8. Dražgoše breads.

In the small village Selce in the Selška valley painting on glass as folk painted fine art was developed at the end of the $18^{\text {th }}$ century and in the early $19^{\text {th }}$ century in the Selška painting workshop. The motives were pious and secular. We mention them in connection with beehive extensions, because often the same master from this work- 
shop also painted beehive extensions. This folk art got its place in farmhouses and became extinct at the beginning of the $20^{\text {th }}$ century ${ }^{27,28}$.

\section{Artistically made honey Loka breads and Dražgoše breads}

The honey Loka small breads and Dražgoše breads (Figures 7 and 8) which, as a historical specialty belong to the folk art associated with food and characterizes the Škofja Loka geographical area from the $17^{\text {th }}$ to the beginning of the $18^{\text {th }}$ century. Initially, they were intended for the townspeople and the nobility, but later they also spread to the countryside. Loka honey breads, called small breads were made in the past in special wooden artistically carved model ${ }^{23}$ by Clarisse nuns and then Ursulines. The models were strictly liturgically religious in content at the beginning. The oldest model is from 1752 . The products were called "nun's lect", which was also extremely artistically decorated; ornaments are based on ancient elements. These breads were different from other small breads due to the different preparation of the dough. The recipes for the preparation remained a monastic secret. A special feature of folk art and handicrafts are also handmade (without models) and artistically decorated Dražgoše breads, from the $18^{\text {th }}$ century. They are named after the village of Dražgoše, where they are traditionally made and have been Slovenian ornamental masterpieces. They are made freehand according to the imagination and skill of the manufacturers; most often shapes of Dražgoše breads are the heart and majolica. Dražgoše breads are made of honey dough and are unique, beautiful and impresivelly decorated with national ornaments, mostly with flowers made of the same dough. The "planika" flower is one of the most commonly depicted flowers. The dough was made from flour, which was initially rye flour, but then replaced with white flour and strongly heated honey, as well as spices and a special leavening agent, called "deer salt". Their production has been symbolically preserved to this day. Artistic making, however, was passed down from generation to generation. In Dražgoše, the custom has been preserved that for the Holy Three Kings, boys give bread hearts to the girls, and girls give the so called "krajčki" to the boys ${ }^{28-34}$.

\section{Artistically shaped butter models}

There is a lot of cheese and butter in the Alpine food pyramid. Butter was poured into beautiful hand-carved wooden models (Figure 9) and therefore the carved "planika" flower, which symbolizes the mountain world is imprinted in butter. This on-going tradition in the Alpine region shows the special attitude towards food as some other folk arts related to food as useful objects from everyday life ${ }^{35}$.

\section{Discussion}

In extensive multi-year anthropological research in the Selška valley and in the area of Škofja Loka hills, within

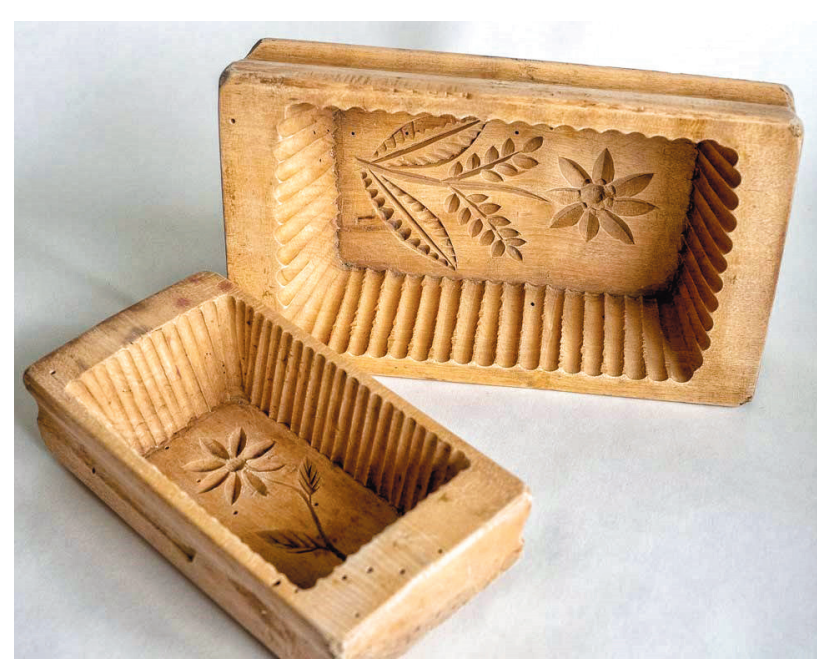

Fig. 9. Hand-carved wooden butter models.

which we study populations from the broadest aspects, we also investigated the connections between nutrition and art and showed the broad dimensions of this field. The research is distinguished by a holistic approach, which allowed us to get a deeper look at the diet of the population of the Selška valley and their history and art. We were able to join this research with extensive anthropological project research. From the very beginning we looked at all phenomena in the investigated population as multifactorial events with the inclusion of a full range of biological, medical, sociological and cultural features.

A whole range of research has been done, and in this context also analyses on diet and eating habits, especially in the interesting hilly villages of Podratitovec, which are much more unspoiled than those in the valleys. In these isolated hilly areas, a very unified diet with many ethnogeographic elements is still present. The research also showed the age-related nutritional stratification and dynamics of food-cultural prevalence and gradual modernization. Given the physical capabilities of the population, the process of aging and fragility, an in-depth study of nutrition is underway. During the course of the recent research, we have recorded the rich cultural and artistic traditions associated with nutrition, which we present in this paper.

Historically, the traditional folk nutrition of Selška valley population was very simple. Among the most common dishes were floury dishes, mushes (from barley, corn, wheat or buckwheat flour), porridges (millet or barley), spoonbread-žganci (corn buckwheat or wheat) and fruit juices, as well as dried fruit. Often, they would mix these dishes with root crops, such cabbage, turnip, potatoes or fruits, mainly with apples and pears. In the past, more meat was eaten compared to vegetables ${ }^{38}$. The analyses of the nutrition in mountainous part of Selška valley show that almost all respondents maintained the traditional habits of Alpine nutrition whose patterns were passed from generation to generation. Our example from mountainous villages in Selška valley clearly shows how nutrition can be also an indicator of isolation. 
We were also able to conclude that the nutrition of mountainous area of Selška valley is qualitatively and quantitatively adequate and balanced with macro and micro components and the rhythm of intake is regular. The number of diet-related diseases identified was not increased, including the goiter. Our research confirmed the significant influence of nutrition on the parameters of growth and development. Children in this area are not nutritionally deprived, which is proved by the comparison of growth curves in various national programmes. Anthropometric measures of body composition in the Selška valley population aged 18 to 75 years showed that this population has "average obesity". Based on the body mass index and components of the average cross section of the upper arm, we have determined that man are relatively more muscular compared to women while women have more fatty tissue. Male and female population of Selška valley is skinnier and more muscular compared to international reference range by Frisancho ${ }^{37}$.

\section{Conclusion}

As part of our observational study of isolated populations conducted in the Selška valley and its surroundings, which included research on nutrition in this area, we were observing elements of nutrition in art in this hilly area. Food and nutrition have been frequently staged in the arts of this area since the Middle Ages. The most interesting are the depictions on frescoes, beehive panels, artistically made honey Loka and Dražgoše breads, artistically shaped butter models and some other folk arts related to nutrition. Art works represent an important historical source that provides a visual dimension of foodstuffs and details of the cooking and presentation of meals. The present research undoubtedly confirmed the usefulness of art works for studying the history of nutrition.

\section{R E F E R E N C E S :}

1. VIDOVIČ M, Loški razgledi 48 (2001) 301. - 2. VIDOVIČ M, Železne niti: Zbornik Selške doline, 11 (2014) 281. - 3. VIDOVIČ M, Anthropology and public health. In: VIDOVIČ M (Ed) Anthropology and public health (NIPH, Ljubljana, 2016). - 4. VIDOVIČ M, SHARRON G, CREWS DE. Coll Antropol, 39 (2015) 297. - 5. VIDOVIČ M, SHARRON G, CREWS DE, Coll Antropol, 36 (2012) 47. - 6. VIDOVIČ M, HISHEH S, SCHMITT L, Ann Hum Biol, 34 (2007) 26. - 7. HADŽIĆ METJAHIĆ N, VIDOVIČ M, ČAKAR J, DŽEHVEROVIĆ M, PILAV A, DOGAN S, MARJANOVIĆ D, Homo, 70 (2019) 129. doi: 10.1127/homo/2019/1036 - 8. TASSO M, LUCCHETTI E, P IZZETTI P, VIDOVIČ M, CARAVELLO G, Coll Antropol, 29 (2005) 327. - 9. MILIČIĆ J, VIDOVIČ M, Homo, 56 (2005) 161. - 10. SIEVERT LL, VIDOVIČ M, HORAK H, ABEL M, Menopause, 11 (2004) 223. - 11. PLETERSKI A, Kuhinjska kultura v zgodnjem srednjem veku / Küchenkultur im frühen Mittelalter (ZRC, Ljubljana, 2008). - 12. MAKAROVIČ G, Slovenski etnograf, 33 (1988-1990) 127. - 13. MAKAROVIČ G, Glasnik Etnografskog muzeja u Beogradu, 50 (1986) 45. - 14. HUNDSBICHLER H, Zgodovinski časopis, 50 (1996) 187. - 15. STELE F, Crngrob (Mladinska knjiga, Ljubljana, 1960). - 16. BAŠ A, Loški razgledi 3 (1956) 175. — 17. STELE F, Ikonografski kompleks slike „Svete Nedelje“v Crngrobu. In: Razprave II (AZU, Ljubljana, 1944). — 18. KOMAN D, Sveta Nedelja - Nedeljski
Kristus in Nedeljska Cerkev. In: KLEMENC A (Ed.) Hodil po zemlji sem naši. Marijanu Zadnikarju ob osemdesetletnici (ZRC, Ljubljana, 2001). - 19. CEVC E, Slovenski etnograf, 3-4 (1951) 180 - 20. SEDEJ I, Etnolog, 4 (1994) 169. - 21. KOMAN D, The painter Jernej of Loka and his work in Loka (Muzejsko društvo, Škofja Loka, 2011). — 22. OVSEC DJ, Praznovanje pomladi in Velike noči na Slovenskem in po svetu (Modrijan, Ljubljana, 2010). - 23. BOGATAJ J, Ustvarjalna Slovenija (Darila Rokus, Ljubljana, 2005). - 24. ŠTUKL F, Po poti kulturne dediščine. Sprehod skozi Škofjo Loko in vasi v spodnjem porečju Poljanske Sore (Muzejsko društvo Škofja Loka, Škofja LOka, 2011). — 25. MAKAROVIČ G, ROGELJ ŠKAFAR B, Poslikane panjske končnice: Zbirka Slovenskega etnografskega muzeja (Slovenski etnografski muzej, Ljubljana; 2000). - 26. GIESEMANN G, Traditiones, 36 (2007) 143. - 27. MAKAROVIČ G, Slovenski etnograf, 15 (1962) 107. -28. SEKIRNIK K, Železne niti 15, (2015) 201. - 29. MOHORIČ BONČA K, Železne niti, 15 (2015) 187. - 30. BOGATAJ RANT A, Železne niti, 7 (2010) 305. - 31. GOLOB F, Loški razgledi, 33 (1986) 85. — 32. STERLE M, Loški razgledi, 28 (1981) 245. —33. LOŽAR R, Etnolog, 10/11 (1937-1939) 169. — 34. OREL B, Etnolog, 10/11 (1937-1939) 198. - 35. KAČAR J, Personal communication. - 36. GODINA GOLIJA M, Etnolog, 24 (2014) 59. - 37. FRISANCHO AR, J Clin Nutr 34 (1981) 2540.

\section{Vidovič}

National Institute of Public Health, Trubarjeva 2, 1000 Ljubljana, Slovenia

e-mail: maruska.vidovic@nijz.si 


\section{ANTROPOLOŠKI POGLED NA PREHRANU I UMJETNOST NA ŠIREM PODRUČJU SELŠKE DOLINE U SLOVENIJI}

\section{SAŽETAK}

Kao dio naše promatračke studije izoliranih populacija provedene u Selškoj dolini s okolinom u sjeverozapadnoj Sloveniji, koja je također obuhvaćala istraživanja o prehrani na ovom području, promatrali smo i elemente prehrane u umjetnosti na ovom planinskom području. Hrana i prehrana često se priređuju u umjetnostima ovog područja od srednjeg vijeka dalje. Najzanimljiviji su prikazi na freskama, pločama od košnica, u umjetnički izrađenim medenim loškim i dražgoškim kruhovima te umjetnički oblikovanim maslacem i predmetima iz svakodnevnog života. 